\title{
Routine application of the polymerase chain reaction for detection of Mycobacterium tuberculosis in clinical samples
}

\author{
G T Noordhoek, J A Kaan, S Mulder, H Wilke, A H J Kolk
}

Public Health Laboratory Friesland, PB 21020, 8900 JA Leeuwarden, The Netherlands G T Noordhoek $S$ Mulder

Public Health Laboratory, Bergsmalaan 1, 7512 AD Enschede, The Netherlands J A Kaan H Wilke

Diakonessen Hospital, PB 80250,

3508 TG Utrecht,

The Netherlands

J A Kaan

N.H. Swellengrebel Laboratory of Tropical Hygiene, Royal Tropical Institute, Meibergdreef 39, 1105 AZ Amsterdam, The Netherlands A H J Kolk

Correspondence to: Dr G T Noordhoek. Accepted for publication 21 February 1995

\begin{abstract}
Aim-To investigate the use of the polymerase chain reaction (PCR) in the routine laboratory for the detection of Mycobacterium tuberculosis in clinical samples.

Methods-Samples were divided and processed separately for the detection of $M$ tuberculosis by microscopy, culture and PCR. After DNA extraction, PCR was performed with primers specific for the insertion element IS6110 and the product was analysed by agarose gel electrophoresis, Southern blotting or dot blotting and hybridisation with a digoxigenin labelled internal probe. Each sample was tested for inhibitors of Taq polymerase with the aid of an internal control. Multiple negative and positive controls were used to monitor each step of the procedure.

Results-The data from two laboratories, using the same operating procedures, were combined. Of 1957 specimens, 79 (4\%) were culture and PCR positive, while 1839 $(93.9 \%)$ were negative in both tests. Thirty specimens $(1.5 \%)$ were PCR positive only and nine $(0 \cdot 5 \%)$ were culture positive but PCR negative.

Conclusion-Using culture and clinical history as the gold standard, sensitivity and specificity for PCR were $92 \cdot 1 \%$ and $99.8 \%$, respectively. With elaborate precautions, PCR is a suitable and reliable method for the detection of $M$ tuberculosis in clinical samples in a routine microbiology laboratory.

(f Clin Pathol 1995;48:810-814)
\end{abstract}

Keywords: Mycobacterium tuberculosis, PCR, application clinical samples.

After years of declining incidence, the number of registered patients with tuberculosis in The Netherlands has increased since $1987 .{ }^{1}$ Rapid diagnosis of infectious cases of tuberculosis is of major importance for public health services. ${ }^{2}$ Drawbacks of the conventional Mycobacterium tuberculosis detection techniques are that direct staining for acid fast bacilli lacks sensitivity and specificity and that culturing of mycobacteria is very time-consuming. Furthermore, microscopy and culture are difficult in cases of extrapulmonary infection, and it is for this reason that some laboratories still use inoculation of guinea pigs for samples which are difficult to obtain. With the polymerase chain reaction
(PCR) it is possible to identify $M$ tuberculosis directly in clinical samples. ${ }^{3}$ Many papers describe the development and the use of DNA amplification methods for detection of $M$ tuberculosis. ${ }^{4}$ However, Noordhoek et al recently showed that reliable detection of $M$ tuberculosis using PCR can be difficult because of the occurrence of false positive results through contamination and lack of sensitivity, usually caused by inhibition of Taq polymerase by biological substances present in the sample. ${ }^{45}$

In The Netherlands, the prevalence of tuberculosis infections is still very low, less than $4 \%$ of the samples submitted to a routine laboratory are culture positive for $M$ tuberculosis. Thus, if the few positive results are not to be missed, the sensitivity of a rapid and specific test needs to be close to $100 \%$. To investigate the feasibility of routine PCR testing in a clinical laboratory, both conventional tests and PCR were carried out on a large number of clinical samples. Insertion sequence IS6110, which is specific for the $M$ tuberculosis complex group of bacteria, was used as the target for DNA amplification..$^{346-8}$ The protocol was optimised to obtain maximal sensitivity and specificity.

\section{Methods}

\section{CLINICAL SPECIMENS}

The samples tested at the microbiology departments of the Leeuwarden or Enschede Public Health Laboratories were routine specimens obtained from patients suspected of having tuberculosis. In Leeuwarden some of the samples were preselected. During the first four months of the project, all sputum and bronchial washings received in the laboratory were included in the study. Thereafter, PCR on sputum and bronchial washings was carried out only when acid fast bacilli were found on microscopy or when there was strong clinical evidence of tuberculosis. On the day of receipt, taking appropriate precautions in a laminar flow hood, the specimens were divided into two portions, one for PCR and one for conventional detection methods. In the mycobacteria laboratory, direct smears were analysed for acid fast bacilli using microscopy after staining with auramine and/or Ziehl-Neelsen. Sputum, bronchial washing and pleural fluid samples were decontaminated using standard procedures ${ }^{9}$ and inoculated onto Löwenstein-Jensen medium. Specimens from other sites of the body were, after standard pretreatment, inoculated onto Löwenstein-Jensen and/or Middlebrook 7H11 medium. 
PRETREATMENT OF SAMPLES FOR PCR

PCR was performed according to the recommendations of Kwok, ${ }^{10}$ using three separate locations for the preparation of the PCR reaction mixture, sample and DNA preparation, and the analysis of PCR products, respectively. Positive displacement pipettes or filtertips were used throughout and for most of the specimens dUTP-uracil-N-glycosylase (UDG) (Gibco-BRL) was used to avoid contamination with amplicons from previous reactions. ${ }^{811}$ Sputum, bronchial washing, pleural fluid, and pus samples were pretreated with 1 to 10 volumes of $0.5 \mathrm{M} \mathrm{NaOH} / 0.05 \mathrm{M}$ sodium citrate $/ 0.5 \% N$-acetyl-L-cysteine and centrifuged for 15 minutes at $15000 \times g$ in a microcentrifuge. Samples which did not need liquefaction, such as urine and cerebrospinal fluid, were concentrated by centrifugation at $15000 \times g$ in a microcentrifuge. The pellets were washed once with a solution containing $1 \%$ Triton X100, $20 \mathrm{mM}$ Tris/ $\mathrm{HCl}(\mathrm{pH} \mathrm{8.3)}$ and $1 \mathrm{mM}$ EDTA (TEX), and resuspended in $100 \mu \mathrm{l}$ TEX. Tissue biopsy specimens were homogenised with razor blades and incubated for 12 to 16 hours at $55^{\circ} \mathrm{C}$ in 100 to $500 \mu \mathrm{l}$ lysis buffer containing $1 \%$ sodium dodecyl sulphate (SDS), $100 \mu \mathrm{g} / \mathrm{ml}$ proteinase $\mathrm{K}$ in $10 \mathrm{mM}$ Tris/ $\mathrm{HCl}(\mathrm{pH} \mathrm{8 \cdot 3})$. Proteinase $\mathrm{K}$ was inactivated by heating at $100^{\circ} \mathrm{C}$ for 15 minutes; $100 \mu \mathrm{l}$ of the lysate was used for further analysis. DNA was extracted from all samples as described previously. ${ }^{12}$ Briefly, $1 \mathrm{ml}$ guanidinium thiocyanate (GuSCN) containing L6 buffer and $25 \mu \mathrm{l}$ silica particles were added to $100 \mu \mathrm{l}$ of the pretreated sample suspension. After thorough mixing, the samples were incubated for 20 minutes at $80^{\circ} \mathrm{C}$ for complete lysis of mycobacteria, followed by 15 to 60 minutes mixing at room temperature to allow binding of the bacterial DNA to the silica particles. The particles were washed twice with L2 buffer, twice with $70 \%$ ethanol and once with acetone. DNA was released by addition of 65 to $100 \mu$ distilled water and incubation for 30 to 60 minutes at $60^{\circ} \mathrm{C}$. The number of samples analysed at any one time was variable, depending on the number of clinical samples sent to the laboratory. To monitor for cross-contamination during pretreatment and DNA extraction, one negative sample to every four or five clinical samples was included in each series. The efficiency of DNA extraction was monitored in each test by including two sputum samples to which 100 or 1000 Mycobacterium bovis BCG bacteria had been added.

\section{POLYMERASE CHAIN REACTION}

PCR was performed using primers INS1 and INS2 homologous for sequences in the insertion sequence IS6110, which is specific for $M$ tuberculosis complex bacteria. ${ }^{36}$ The extracted DNA $(10 \mu \mathrm{l})$ was added to $40 \mu \mathrm{l}$ of PCR mixture. In Leeuwarden the samples were also tested at a 10-fold dilution. The PCR mixture was prepared as described previously. ${ }^{3}$ dUTP was used instead of dTTP and 0.2 to 0.02 units of UDG were added per $40 \mu$ l of PCR mixture. ${ }^{8}$ Two approaches were used to check each sample for inhibition of Taq polymerase. In Leeuwarden 50 fg DNA from recombinant Mycobacterium smegmatis strain 1008 was added to the PCR mixture. M smegmatis 1008 contains a modified IS 6110 sequence. ${ }^{13}$ When this modified IS6110 sequence is amplified using primers INS1 and INS2, a 301 base pair fragment is obtained which is distinguishable from the 245 base pair PCR product from $M$ tuberculosis on agarose gel electrophoresis. In Enschede $10 \mathrm{fg}$ of $M$ tuberculosis DNA was added to a duplicate of each sample. ${ }^{8}$

Performance of the amplification reaction was monitored by testing one sample without DNA and three samples containing $2 \cdot 5,25$ and $250 \mathrm{fg} M$ tuberculosis DNA. The PCR was performed in a thermocycler (Perkin Elmer 480 or Bio-med 60 for Leeuwarden and Enschede, respectively). In Leeuwarden the PCR cycle profile was optimised by using a "touch down" protocol to increase the specificity of the reaction. ${ }^{14}$ The reaction started with six minutes at $37^{\circ} \mathrm{C}$ for UDG incubation and six minutes at $94^{\circ} \mathrm{C}$ for UDG inactivation and DNA denaturation, followed by PCR cycles of one minute at $94^{\circ} \mathrm{C}$ for denaturation, one minute for primer annealing and one minute for primer extension at $72^{\circ} \mathrm{C}$. The annealing temperature of the first 10 cycles was decreased by $1^{\circ} \mathrm{C}$ every second cycle from $70^{\circ} \mathrm{C}$ to $66^{\circ} \mathrm{C}$, followed by 40 cycles with an annealing temperature of $65^{\circ} \mathrm{C}$. In Enschede the PCR cycle profile was used as described previously. ${ }^{3}$ PCR products were kept at $72^{\circ} \mathrm{C}$ until analysis.

\section{ANALYSIS OF PCR PRODUCTS}

In Leeuwarden $10 \mu \mathrm{l}$ of the amplification product was examined by ethidium bromide agarose gel electrophoresis and Southern blotting. In Enschede the products were analysed by dot blotting. In both laboratories the blots were hybridised with an internal 188 base pair probe which was labelled with digoxigenin during amplification of $M$ tuberculosis DNA. ${ }^{3}$ Probetarget hybrids were detected using the DIG nucleic acid detection kit (Boehringer Mannheim) as recommended by the manufacturer. Results were considered valid only if all controls were correct. Samples with a negative PCR result were only reported as negative when there was no evidence of inhibition in the sample. Samples with a positive result for $M$ tuberculosis were retested for confirmation.

\section{Results}

COMPARISON OF PROCEDURES OF THE TWO LABORATORIES

This study combines the results from two laboratories using similar protocols for detecting $M$ tuberculosis by PCR. The sensitivity of the procedures in both laboratories was compared by testing serial dilutions of chromosomal $M$ tuberculosis DNA and by exchanging sets of test sputum samples containing 100 and 1000 $M$ bovis BCG bacteria. The two laboratories had the same level of detection. 


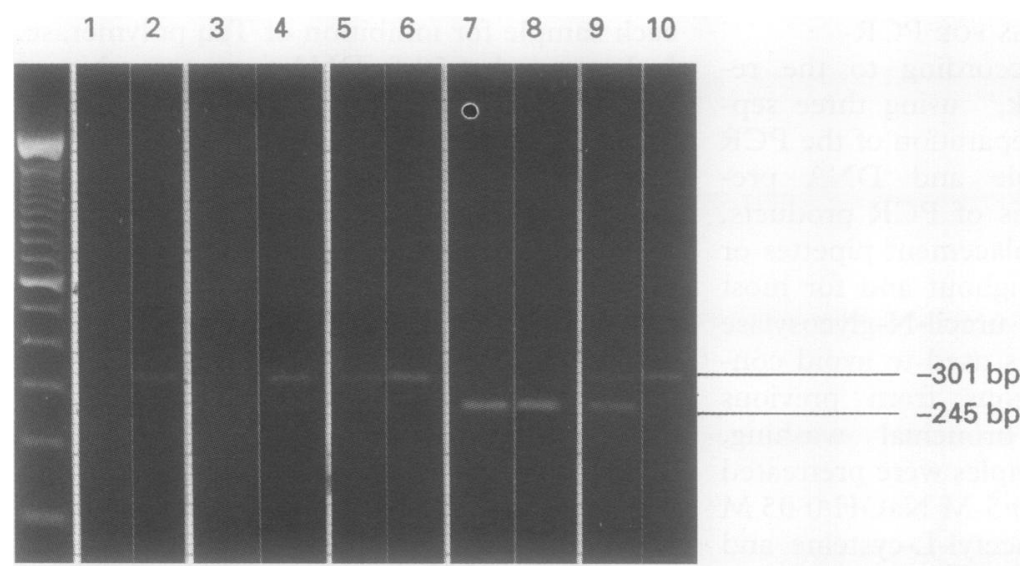

Ethidium bromide stained agarose gel with $P C R$ products from five clinical samples. $M$ smegmatis 1008 DNA was added to the PCR mixture. Odd lanes, undiluted samples; even lanes, samples diluted 10-fold before PCR. Lanes 1, 2, 5, and 6, M tuberculosis negative samples; lanes 3, 4 and 7 to 10 , positive samples. The first lane contains a 100 base pair (bp) ladder. The position of the 301 base pair product from M smegmatis 1008 and the 245 base pair product from $M$ tuberculosis are indicated.

\section{INHIBITION OF TAQ POLYMERASE}

All samples were tested for the presence of substances inhibiting Taq polymerase by using $M$ smegmatis 1008 DNA or by spiking duplicate samples with $M$ tuberculosis DNA. Inhibition was found in a few samples (figure, lanes 1 and 3). In many cases inhibition disappeared after the extracted DNA was diluted 10-fold (figure, lanes 2 and 4). However, dilution also decreased the detection limit of the test. This was shown in smear negative samples in which only a few colonies of mycobacteria were cultured. Undiluted samples were PCR positive, whereas the samples diluted 10 -fold were negative (figure, lanes 9 and 10). The undiluted samples contained the minimal amount of target DNA to give a detectable PCR product. In Leeuwarden no PCR result could be obtained in nine $(1.5 \%)$ of 605 samples because of persistent inhibition. In Enschede, where samples were not routinely tested at the 10 -fold dilution, 61 $(4 \cdot 1 \%)$ of 1494 samples showed inhibition.

\section{COMPARISON OF MICROSCOPY, CULTURE AND} PCR RESULTS

Over 14 months, 2099 specimens from 1638 different patients were submitted for detection of $M$ tuberculosis by microscopy, PCR and cul-

Table 1 Comparison of culture and PCR results for 1957 clinical specimens

\begin{tabular}{|c|c|c|c|c|}
\hline & \multicolumn{2}{|c|}{$M$ tuberculosis culture positive } & \multicolumn{2}{|c|}{$M$ tuberculosis culture negative } \\
\hline & $\begin{array}{l}P C R \\
\text { positive }\end{array}$ & $\begin{array}{l}P C R \\
\text { negative }\end{array}$ & $\begin{array}{l}P C R \\
\text { positive }\end{array}$ & $\begin{array}{l}P C R \\
\text { negative }\end{array}$ \\
\hline $\begin{array}{l}\text { Sputum } \\
\text { Bronchial washings } \\
\text { Pleural fluid } \\
\text { Urine } \\
\text { Pus } \\
\text { Blood } \\
\text { Cerebrospinal fluid } \\
\text { Tissue biopsy } \\
\text { Ascites } \\
\text { Cervical smear } \\
\text { Stomach } \\
\text { Total }\end{array}$ & $\begin{array}{r}49 \\
26 \\
0 \\
0 \\
3 \\
0 \\
0 \\
0 \\
0 \\
0 \\
1 \\
79\end{array}$ & $\begin{array}{l}2 \\
2 \\
2 \\
1 \\
1 \\
0 \\
0 \\
1 \\
0 \\
0 \\
0 \\
9\end{array}$ & $\begin{array}{r}7 \\
10 \\
12 \\
0 \\
1 \\
0 \\
0 \\
0 \\
0 \\
0 \\
0 \\
30\end{array}$ & $\begin{array}{r}334 \\
889 \\
270 \\
129 \\
142 \\
22 \\
23 \\
22 \\
7 \\
1 \\
0 \\
1839\end{array}$ \\
\hline
\end{tabular}

ture. No culture results were obtained in 55 specimens because of contamination with other bacteria. In 17 samples mycobacteria other than $M$ tuberculosis were cultured. Persistent inhibition of Taq polymerase was found in 70 samples. These 142 samples were not evaluated further in this study.

The results of the $M$ tuberculosis PCR were compared with culture for $M$ tuberculosis in 1957 specimens (table 1 ). Of the samples, $4 \%$ were culture and PCR positive and $94 \%$ were negative in both tests. Thirty samples were PCR positive and culture negative. Of these 30 samples, 26 originated from patients with clinical symptoms of tuberculosis or from patients in whom a previous sample was culture positive. Most of these patients were receiving treatment with antituberculosis drugs. The positive PCR supported the clinical diagnosis of tuberculosis and it is unlikely that these positive PCR results were due to contamination of samples with $M$ tuberculosis or with amplicons. The remaining four samples came from three different patients. Retesting of extracted DNA from one patient's pleural fluid sample resulted in weak equivocal PCR products. New DNA extracts from the two other patients were also weakly positive on PCR. The clinical histories of the three patients did not show evidence of tuberculosis infection at investigation or one year after sampling. Although dUTP was used throughout, UDG was not used during the early phase of the study. These positive results occurred during this early period. Therefore, we have to regard these PCR results as probable false positives. Contamination might have occurred during pretreatment or DNA extraction.

We found nine PCR negative samples, although acid fast bacilli were observed in direct smears and $M$ tuberculosis was cultured. The $M$ tuberculosis strains cultured from these samples were all PCR positive, indicating that the IS6110 fragment was present. The negative PCR results in these clinical specimens were probably because of unequal distribution of mycobacteria in the sample. In the smear preparations few acid fast bacilli were observed and only one or two of the three inoculated tubes containing Löwestein-Jensen medium were positive.

To evaluate our PCR, we have used the definitions "true" positive and "true" negative. We regarded a test result as "true" positive when $M$ tuberculosis was cultured, when direct microscopy and PCR were positive but culture was negative and when direct microscopy and culture were negative but PCR was positive and other material from the patient was positive on culture or had been positive in the past. In table 2 the results of culture, microscopy and PCR are compared using the definitions as described above. These results show that our PCR test has a specificity of $99.8 \%$ and a sensitivity of $92 \cdot 1 \%$, whereas culture had a sensitivity of $77 \cdot 2 \%$. In total, the PCR test was positive in $34(1.7 \%)$ "true" positive samples with a negative microscopy result.

Hybridisation of blots increased the sensitivity of the test (data not shown). In a few 
Table 2 Comparison of results obtained on culture, smear and PCR with true positives and true negatives

\begin{tabular}{|c|c|c|c|c|c|c|c|c|}
\hline & \multicolumn{4}{|c|}{ True positive $(n=114)$} & \multicolumn{4}{|c|}{ True negative $(n=1843)$} \\
\hline & \multicolumn{2}{|l|}{ Culture positive } & \multicolumn{2}{|l|}{ Culture negative } & \multicolumn{2}{|l|}{ Culture positive } & \multicolumn{2}{|l|}{ Culture negative } \\
\hline & Smear positive & Smear negative & Smear positive & Smear negative & Smear positive & Smear negative & Smear positive & Smear negative \\
\hline $\begin{array}{l}\text { PCR positive } \\
\text { PCR negative }\end{array}$ & $\begin{array}{r}63 \\
9\end{array}$ & $\begin{array}{r}16 \\
0\end{array}$ & $\begin{array}{l}8 \\
0\end{array}$ & $\begin{array}{r}18 \\
0\end{array}$ & $\begin{array}{l}0 \\
0\end{array}$ & $\begin{array}{l}0 \\
0\end{array}$ & $\begin{array}{l}0 \\
0\end{array}$ & $\begin{array}{r}4 \\
1839\end{array}$ \\
\hline
\end{tabular}

cases a 245 base pair band was not visible on the gel and was only detected after hybridisation of the Southern blot. Hybridisation was also necessary to control the specificity of the reaction. We found that a Nocardia farcinica isolate from a sputum sample produced a 245 base pair fragment after PCR with the INS1INS2 primer set which did not hybridise with the 188 base pair internal probe. This PCR product will be analysed further.

\section{Discussion}

PCR is a rapid, sensitive and specific DNA amplification technique for the detection of $M$ tuberculosis. Most $M$ tuberculosis complex strains contain multiple copies of the insertion sequence IS6110, which makes this element a widely used target for amplification. Recently, about seven $M$ tuberculosis strains lacking IS6110 have been reported. ${ }^{15-17}$ However, these strains were isolated from patients in South East Asia and all European strains tested to date contain one or more IS6110 copies (D van Soolingen, personal communication). We consider the IS 6110 element to be suitable for the detection of $M$ tuberculosis infection in our region.

Three studies have described the feasibility of using a PCR test in the routine clinical laboratory where many samples, including a large proportion of negative specimens, need to be tested daily. ${ }^{18-20}$ Using PCR without prior DNA purification, Clarridge et al reported a sensitivity of $86 \cdot 1 \%$, while $7 \cdot 3 \%$ of the specimens contained Taq polymerase inhibitors. ${ }^{18}$ Forbes et al achieved a sensitivity of $87 \cdot 2 \%$ without monitoring for inhibition. ${ }^{19}$ Nolte et al used internal controls during PCR and reported that Taq polymerase was inhibited in 10 to $17 \%$ of sputum samples when no DNA purification was performed. ${ }^{20}$ After phenol extraction the inhibiting substances were removed from all samples. Inhibition of Taq polymerase is a problem described by many investigators. ${ }^{321-24}$ We have chosen a PCR method with a DNA extraction procedure in which each individual sample is monitored for enzyme inhibition in order to achieve the highest possible sensitivity. In The Netherlands the number of culture positive specimens does not exceed $4 \%$, so we considered sensitivity a priority. We found that, even after DNA extraction with GuSCN and silica particles, some samples contained inhibiting substances. Dilution of the sample led to some decrease in sensitivity although, for many samples, the benefit of diluting the inhibiting substances was larger. Alternatively, phenol extraction followed by ethanol precipitation will remove inhibitors from GuSCN/silica purified DNA. A nested
PCR will also improve sensitivity. ${ }^{2526}$ However, nested PCR is not recommended in a routine laboratory in view of the risk of contamination with amplicons.

Commercial tests based on nucleic acid amplification for the detection of $M$ tuberculosis in samples from the respiratory tract are now available. ${ }^{27-30}$ However, the commercial tests are rather expensive and need further development. Experience obtained from in house DNA amplification tests shows that commercial test systems need to include controls which enable one to monitor individual specimens for the presence of enzyme inhibitors. ${ }^{31}$

We did not encounter false positive results caused by contamination with amplicons as dUTP-UDG was used in the reaction mixture and because the laboratory procedures described by Kwok were followed. ${ }^{810}$ However, carry-over of bacteria or DNA sometimes occurred from a sample with a high load of $M$ tuberculosis bacteria. The use of tubes with screw caps for the extraction procedure solved this problem.

The percentage of positive samples in this study, $5 \%$, is not representative of the specimens received by our laboratories because some of the samples were preselected. If all sputum and bronchial washing samples had been analysed, we would have expected the number of positive results to be not more than $3 \%$, which is the mean prevalence for The Netherlands. All samples were investigated within a week of receipt, so the PCR results were available much earlier than the culture results and could be used for clinical management.

A PCR test result needs to be interpreted in its clinical context. A PCR positive result does not always conform to culture results-for example, the case of a 30 year old man with suspected early pulmonary tuberculosis. On admission, the patient's sputum sample was positive on microscopy and PCR, but was culture negative. Two weeks later all three tests were positive. After 76 days of treatment with antituberculosis drugs, sputum was negative on microscopy but was culture and PCR positive. On day 188 , only the PCR was positive. The first specimen was regarded as positive because it was positive on both microscopy and PCR. The last specimen was interpreted as positive based on the clinical presentation of the consecutive specimens.

Although the routine use of PCR is expensive, we conclude that, when combined with microscopy, nucleic acid amplification is very useful for the rapid and specific detection of $M$ tuberculosis DNA in respiratory tract samples. Furthermore, for investigation of pleural fluid and extrapulmonary samples such as tissue biopsy specimens and cerebrospinal 
fluid, PCR has become a reliable and sensitive alternative to inoculation of guinea pigs (data not shown). Animal testing is no longer necessary for the diagnosis of tuberculosis. PCR can also be used to identify mycobacterial species rapidly. Discrimination between $M$ tuberculosis complex bacteria and other mycobacterial species is essential for adequate treatment and isolation of the patient.

PCR is not a substitute for culture unless a wide spectrum of mycobacterial species can be detected. If such a test becomes available, a routine laboratory could use PCR to screen all incoming respiratory and extrapulmonary samples and perform culture only on the PCR positive samples in order to test antibiotic susceptibility. The cost of such an approach will be offset by the benefit to patients, in whom treatment is instituted only when the presence of mycobacteria has been confirmed, and the savings gained by restricting culture only to those samples containing mycobacteria.

At present, PCR is an important addition to the routine battery of laboratory tests for the rapid and definitive diagnosis of tuberculosis.

We thank J E Degener and J D A van Embden for stimulating discussion, J Spoelstra for linguistic assistance and J de Haan for typing the manuscript.

1 Royal Netherlands Tuberculosis Association. Guidelines for treatment and prevention of tuberculosis in the Netherlands. The Hague: Royal Netherlands Tuberculosis Association, 1993.

2 Bloom BR, Murray CJL. Tuberculosis: commentary on a reemergent killer. Science 1992;257:1055-64.

3 Kolk AHJ, Schuitema ARJ, Kuijper S, Leeuwen van J, Hermans PWM, Embden van JDA, et al. Detection of Mycobacterium tuberculosis in clinical samples by using polymerase chain reaction and a nonradioactive detection system. f Clin Microbiol 1992;30:2567-75.

4 Noordhoek GT, Kolk AHJ, Bjune G, Catty D, Dale JW, Fine PEM, et al. Sensitivity and specificity of PCR for detection of Mycobacterium tuberculosis: a blind comparison study among seven laboratories. $\mathcal{f}$ Clin Microbio 1994;32:277-84.

5 Noordhoek GT, van Embden JDA, Kolk AHJ. Questionable reliability of the polymerase chain reaction in the detection of Mycobacterium tuberculosis. N Engl f Med 1993;329: 2036.

6 Hermans PWM, Soolingen van D, Dale JW, Schuitema ARJ, McAdam RA, Catty D, et al. Insertion element IS986 from Mycobacterium tuberculosis: a useful too for diagnosis and epidemiology of tuberculosis. $f$ Clin Microbiol 1990;28:2051-8.

7 Thierry D, Brisson-Noël A, Vincent-Lévy-Frébault V, Nguyen S, Guesdon J, Gicquel B. Characterization of a Mycobacterium tuberculosis insertion sequence, IS 6110 , and its application in diagnosis. $\mathcal{F}$ Clin Microbiol 1990;28: 2668-73.

8 Kox LFF, Rhienthong D, Medo Miranda A, Udomsantisuk $\mathrm{N}$, Ellis $\mathrm{K}$, van Leeuwen J, et al. A more reliable PCR for detection of Mycobacterium tuberculosis in clinical samples. $\mathcal{f}$ Clin Microbiol 1994;32:672-8.

9 Kent PT, Kubica GP. Public health mycobacteriology. $A$ guide for the level III laboratory. Atlanta: Centers for Disease Control, 1985

$10 \mathrm{Kwok}$ S, Higuchi R. Avoiding false positives with PCR. Nature 1989;339:237-8.

11 Longo MC, Berninger MS, Hartley JL. Use of uracil DNA glycosylase to control carry-over contamination in polymerase chain reactions. Gene 1990;93:125-8.

12 Boom R, Sol CJA, Salimans MMM, Jansen CL, Wertheimvan Dillen PME, van der Noordaa J. Rapid and simple methods for purification of nucleic acids. $\mathcal{F}$ Clin Microbiol 1990;28:495-503.

13 Kolk AHJ, Noordhoek GT, de Leeuw O, Kuijper S, van Embden JDA. Mycobacterium smegmatis strain for detection of Mycobacterium tuberculosis by PCR used as internal control for inhibition of amplification and for quantification of bacteria. $\mathcal{F}$ Clin Microbiol 1994;32:13546.

14 Don RH, Cox PT, Wainwright BJ, Baker K, Mattick JS. "Touchdown" PCR to circumvent spurious priming dur-

15 Das S, Chan SL, Allen BW, Mitchison DA, Lowrie DB. Application of DNA fingerprinting with IS986 to sequential mycobacterial isolates obtained from pulmonary tuberculosis patients in Hong Kong before, during and after short-course chemotherapy. Tubercle Lung Dis 1993; 74:47-51.

16 van Soolingen D, de Haas PEW, Hermans PWM, Groenen PMA, van Embden JDA. Comparison of various repetitive DNA elements as genetic markers for strain differentiation and epidemiology of Mycobacterium tuberculosis. $\mathcal{f}$ Clin Microbiol 1993;31:1987-95.

17 Yuen LKW, Ross BC, Jackson KM, Dwyer B. Characterization of Mycobacterium tuberculosis from Viacterization of Mycobacterium tuberculosis from $\mathrm{Vi-}$ Microbiol 1993;31:1615-18.

18 Clarridge JE III, Shawar RM, Shinnick TM, Plikaytis BB. Large-scale use of polymerase chain reaction for detection of Mycobacterium tuberculosis in a routine mycobacteriology laboratory. F Clin Microbiol 1993;31:204956.

19 Forbes BA, Hicks KES. Direct detection of Mycobacterium tuberculosis in respiratory specimens in a clinical laboratory by polymerase chain reaction. $\mathcal{f}$ Clin Microbiol 1993; 31:1688-94.

20 Nolte FS, Metchock B, McGowan JE Jr, Edwards A, Okwumabua $\mathrm{O}$, Thurmond $\mathrm{C}$, et al. Direct detection of Mycobacterium tuberculosis in sputum by polymerase Mycobacterium tuberculosis in sputum by polymerase
chain reaction and DNA hybridization. $f$ Clin Microbiol 1993;31:1777-82.

21 Brisson-Noël A, Aznar C, Chureau C, Nguyen S, Pierre $\mathrm{C}$, Bartoli $\mathrm{M}$, et al. Diagnosis of tuberculosis by DNA amplification in clinical practice evaluation. Lancet 1991; 338:364-6.

22 Andersen ÅB, Thybo S, Godfrey-Faussett P, Stoker NG. Polymerase chain reaction for detection of Mycobacterium tuberculosis in sputum. Eur $\mathcal{F}$ Clin Microbiol Infect Dis 1993;12:922-7.

23 Soini H, Skurnik M, Liippo K, Tala E, Viljanen MK. Detection and identification of mycobacteria by amDetection and identification of mycobacteria by am-
plification of a segment of the gene coding for the 32plification of a segment of the gene coding for the
kilodalton protein. $₹$ Clin Microbiol 1992;30:2025-8.

24 Eisenach KD, Sifford MD, Cave MD, Bates JH, Crawford JT. Detection of Mycobacterium tuberculosis in sputum samples using a polymerase chain reaction. Am Rev Respir Dis 1991;144:1160-3.

25 Noordhoek GT, Wolters ECh, de Jonge MEJ, van Embden JDA. Detection by polymerase chain reaction of Treponema pallidum DNA in cerebrospinal fluid from neurosyphilis patients before and after antibiotic treatment. $\mathcal{f}$ Clin Microbiol 1991;29:1976-84.

26 Miyazaki Y, Koga H, Kohno S, Kaku M. Nested polymerase chain reaction for detection of Mycobacterium tuberchain reaction for detection of Mycobacterium tuber32 .

27 Abe C, Hirano K, Wada M, Kazumi Y, Takahashi M, Fukasawa Y, et al. Detection of Mycobacterium tuberculosis in clinical specimens by polymerase chain reaction and gen-probe amplified Mycobacterium tuberculosis direct test. $\mathscr{f}$ Clin Microbiol 1993;31:3270-4.

28 Jonas V, Alden MJ, Curry JI, Kamisango K, Knott, CA, Lankford $\mathrm{R}$, et al. Detection and identification of Mycobacterium tuberculosis directly from sputum sediments by amplification of rRNA. $₹$ Clin Microbiol 1993;31:2410-16.

29 Miller N, Hernandez SG, Cleary TJ. Evaluation of GenProbe Amplified Mycobacterium tuberculosis Direct Test and PCR for direct detection of Mycobacterium tuberand PCR for direct detection of Mycobacterium tuberculosis

30 Pfyffer GE, Kissling P, Wirth R, Weber R. Direct detection of Mycobacterium tuberculosis complex in respiratory specimens by a target-amplified test system. $\mathcal{F}$ Clin Microbiol 1994;32:918-23

31 Bodmer T, Gurtner A, Schopfer K, Matter L. Screening of respiratory tract specimens for the presence of Mycobacterium tuberculosis by using the gen-probe amplified Mycobacterium tuberculosis direct test. $\mathcal{f}$ Clin Microbiol 1994;32:1483-7. 